\title{
A FENNTARTHATÓ FOGYASZTÓI MAGATARTÁS VIZSGÁLATA A TEJ ÉS TEJHELYETTESÍTÓK PIACÁN
}

\author{
ho \\ EXAMINATION OF SUSTAINABLE CONSUMER BEHAVIOUR IN THE MARKET OF MILK \\ AND MILK SUBSTITUTES

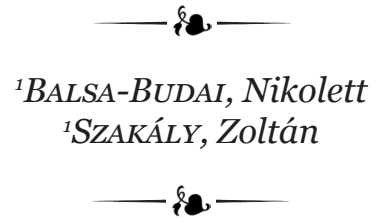

${ }^{1}$ Debreceni Egyetem, Gazdaságtudományi Kar, Marketing és Kereskedelem Intézet (University of Debrecen, Faculty of Economics and Business, Institute of Marketing and Commerce) H-4032 Debrecen, Böszörményi út 138.

e-mail: budai.nikolett@econ.unideb.hu

\begin{abstract}
田 The purpose of this study was to discover the impact of the transitioning consumer habits on the dairy industry's situation and products. The dairy sector faces more and more challenges, such as sustainability concerns and the appearance of substance alternatives. Milk, as a product, is considered a fundamental component of our nutrition; therefore, the industry needs to keep up with consumer preferences. In connection with the plant-based drinks and milk alternatives (clean milk, laboratory milk, egg-based milk replacements) that are getting more and more popular, the question may arise: to what extent can milk-based products be replaced? Is there a product which, from all aspects, is a perfect alternative to milk? In order to answer these questions, we studied the current market position of milk, and the relevant challenges of the industry, mainly from the aspect of sustainability. Then we examined the characteristics and consumer perception of the plant-based drinks that are aimed to replace it. Finally, we took a look at the possible market situation of another replacement product, clean milk, which is expected to be released soon. The results called our attention to that the milk industry is probably awaiting transformation where new technological solutions, such as the spread of more ethical animal husbandry, are set to become the main direction. Such product will also represent a higher value for consumers, which will impact the price of these products. Although plant-based drinks' market share shows dynamic growth, currently, there is no product available that can perfectly replace milk from all points of view. However, it is essential to note that milk replacements produced by various innovative technologies will expectably appear on the market as new competitors.
\end{abstract}

KuLCSSZAVAK: fenntartható fogyasztás, tejipar, növényi alapú tejhelyettesítő, tiszta tej
KEYWORDS: sustainable consumption, dairy sector, plant-based milk alternatives, clean milk

JEL-Kódok (JEL CoDES): Q13, O13, O33, A13

DOI: https://doi.org/10.34100/TEJGAZDASAGvol78iss1-2pp3-17

\section{BEVEZETÉS - INTRODUCTION}

Az utóbbi években a táplálkozás terén sosem látott módon gyorsult fel a fogyasztók attitűdjeinek változása. Azonban egyre inkább érezhető egy bizonyos új irány létrejötte, ahol olyan értékek alakítják a fogyasztói preferenciákat, mint az egészség- és környezettudatosság vagy az etikusság. Úgy tűnik, az alapvető élelmiszerek terén is egyfajta elvárássá válik a gyártókkal szemben, hogy termékeik környezetbarát és etikus módon kerüljenek előállításra. Fogyasztásuk pedig segítse elő az egészségmegőrzést, a maximális ízélmény garantálása mellett. 
Mindeközben a tej, mint hagyományos termék, a táplálkozás egyik alapvető építőköve, egyre több kihívással kényszerül szembenézni, ami a jelenlegi piaci pozíciójára is hatással lehet.

A tejipart az elmúlt időszakban számtalan kritika érte, miszerint termékei fenntarthatósági szempontból megkérdőjelezhetők (NOYA et al., 2018; HAAS et al., 2019; NARANJO et al., 2020; SILVA et al., 2020). Az ezzel kapcsolatos kommunikáció eredményeképpen évről évre egyre több vásárló dönt úgy, hogy helyettesítő terméket keres és abbahagyja vagy csökkenti a tejtermékek fogyasztását. Ezzel párhuzamosan egyre több olyan fenntarthatóság iránt elkötelezett fogyasztói csoport (LOHAS Lifestyle Of Health and Sustainability, LOVOS Lifestyle Of Voluntary Simplicity) jelenik meg a piacon, amelynek gazdasági ereje is számottevő (SZAKÁLY et al., 2017; BALSA-BUDAI és SZAKÁLY, 2018). Ezek a fogyasztói csoportok elsősorban olyan termékeket vásárolnak, amelyek összeegyeztethetőek az értékrendjükkel. Mindkét csoport elkötelezett a fenntarthatóság iránt, azonban nem teljesen azonos értékeket képviselnek fogyasztásuk során. A LOHAS fogyasztók esetében a környezet- és egészségtudatosságon túl az etikusság és az autentikusság is megjelenik a vásárlási döntéseik során. Fogyasztási értékrendjüket emellett az individualizmus is jelentősen befolyásolja, így fontos számukra, hogy a vásárolt termékek egyfajta önkifejezési eszközzé váljanak. Mindeközben azonban a hedonista életmódról sem kívánnak lemondani, igénylik, hogy a termékek ízélménye maximális legyen, a beszerzésük és elkészítésük pedig egyszerü és kényelmes. A LOVOS csoport szintén hasonló értékekkel rendelkezik, azonban náluk az önellátásra való törekvés erősebben jelenik meg, míg az individuum háttérbe szorul. Mindkét fogyasztói csoport mérete dinamikusan fejlődött az utóbbi években és várhatóan egyre több fogyasztó csatlakozik majd hozzájuk (BALSA-BUDAI et al., 2019).

Annak érdekében, hogy meg tudjuk ítélni a tej és a fenntartható fogyasztás kapcsolatát, a következőkben sorra vesszük azokat a szempontokat, amelyek miatt egyes fogyasztók felhagyhatnak a tejtermékek vásárlásával és helyettesítő termékeket kereshetnek.

\section{A TEJ ÉS A FENNTARTHATósÁG -}

\section{MilK AND Sustainability}

A tej előállítása és fogyasztása számos kérdést vetett fel az elmúlt években, és a szakirodalom alapján kijelenthető, hogy jelenleg nincs egységesen elfogadott álláspont a szakértők részéről sem (SCHMIDT, 2019), ezért törekedtünk a témát több szemszögből megközelíteni.

A régebbi táplálkozási ajánlások szerint egyértelmű volt, hogy a magas áványianyag-, vitamin-, aminosav- és fehérjetartalmának köszönhetően az egészséges táplálkozás nélkülözhetetlen építőköveként tekintettek a tejre. A legtöbb fejlett országban, így hazánkban is, szerepel a táplálkozási ajánlások között a fogyasztása - Ausztriában például napi háromszori tejfogyasztás ajánlott a magas kalcium-, fehérje- és vitamintartalmának köszönhetően (MDOSZ, 2016; HAAS et al., 2019). Azonban ellenpéldát is találhatunk, például Kanada esetében, ahol az új táplálkozási irányelvekben a növényi alapú fehérjék kerültek ajánlásra az állati eredetű tejek és sajtok fogyasztása helyett (NARCITY, 2019). Hazánkban a lakosság egy főre jutó tejfogyasztása jelenleg elmarad a táplálkozási ajánlásokban meghatározott mennyiségtől (260-270 kg/fő/év) és az EU tagországainak átlagától (fóleg a savanyított tejtermékek, ízesített tejitalok, túró, sajt, vaj és sűrített tej esetében). Fontos megjegyezni, hogy a nem elégséges tejfogyasztás elősegítheti a „magyar néma járványként" is emlegetett csontritkulás kialakulását (BALOGH, 2016).

Ennek ellenére a tej egészségre gyakorolt pozitív hatásai mellett egyre több negatív jelző jelenik meg a fogyasztói köztudatban (MYLAN et al., 2019; SILVA et al., 2020). Ide tartozik a laktózérzékenység, amely egyes források szerint a világ felnőtt lakosságának 75\%-ánál jelentkezik, habár ez az arány országonként és földrészenként nagy eltérést mutat (afrikai és ázsiai országok esetében akár a 90\%-ot is elérheti, míg az északi országok esetében ez az arány csupán 1-5\%) (SILVA et al., 2020; PRIBILA et al., 2000). Ez elsősorban annak köszönhető, hogy bár születéskor a legtöbb ember rendelkezik a tejcukor lebontásához szükséges laktáz enzimmel, azonban felnőttkorra döntő többségben ennek az enzimnek a termelése megszűnik. Emellett szintén nö- 
vekedést mutat a tejfehérje-allergiások száma is, elsősorban csecsemő- és kisgyermekkorban jelentkező allergia, ami az esetek nagy részében a kor előrehaladtával megszűnik. Habár a laktózérzékenyek számára megoldást nyújthat a laktózmentes tej, azonban ugyanez nem mondható el a tejfehérje-allergia esetén.

Magyarországon eddig A1-es, illetve A1-A2es béta-kazein fehérje genotípusú tej fogyasztása volt a jellemző. Kutatások alapján az A2-es tej nem tartalmazza azt a fehérje típust, ami az emésztési problémák okozója. A tej összetétele a szarvasmarha fajtájától függ elsősorban. Az A1, ugyanis a problémákat okozó fehérje egy több ezer évvel ezelőtti genetikai mutációjának eredménye, amely a Bos Taurus Taurus, európai szarvasmarhában jelent meg, de a jelenlegi fajtákban ma eltérő arányban van jelen (AGRO JEGER, 2021). Az A1 emésztése során béta-kazomorfin termelődik, aminek emésztéséhez speciális enzimre (DPP4) van szükség. Egyes emberek ezt az enzimet nem állítják elő és ezáltal a béta-kazomorfin gyulladást okozhat. Az A2-nél béta-kazomorfin nem termelődik. Az A2 térnyerése megoldás lehet az egyre növekvő számú tejfehérje-allergiás fogyasztó számára. Az allergiával való küzdelem mellett azonban más szempontok, így például az egészségtudatosság, miatt is egyre többen mondanak le az állati tejról. Ide sorolhatók azok a fogyasztók, akik a tejtől kalóriatartalma miatt pártolnak el és helyette az alacsonyabb energiatartalmú növényi ital felé fordulnak. Emellett pedig vannak olyan fogyasztók, akik szerint az állati tej fogyasztása természetellenes, hiszen az embert kivéve más faj nem fogyaszt más állat által termelt tejet (MYLAN et al., 2019).

A környezeti szempontok szintén megjelennek a fóbb indokok között. A tej- és a húsipart ugyanazok a vádak illetik ezen a téren miszerint, ha az emberek kevesebb állati eredetü terméket fogyasztanának, akkor kevesebb állatot kellene eltartania a bolygónak, csökkenne a szarvasmarhák által termelt üvegházhatású gázok mennyisége, illetve az általuk elfogyasztott takarmány egy részét emberi fogyasztásra lehetne fordítani (AYDAR et al., 2019; LAASSAL és KALLAS, 2019). Más nézőpont szerint azonban a legeltetéses állattartás feltétele a biodiverzitás biztosításának (a legeltetés hiánya kevésbé változatos növényvilág kialakulásához, míg a trá- gya hiánya a rovarok, majd ezáltal a madarak eltűnéséhez vezetne). Tehát a kérődző állatállomány radikális lecsökkentése szintén káros következményekkel járhat (AGRÁRSZEKTOR, 2020c). Ezek a megnyilatkozások nem térnek ki viszont a vadon élő kérődzőkre, mint a szarvasra, őzre, a zsiráfra, antilopra, tevére, gnúra, bölényre, jakra és bivalyra.

Harmadik szempontként megjelenik az etikusság. Sokan amiatt hagynak fel a tej fogyasztásával, mert állatjóléti szempontból etikátlannak tartják a tejgazdaságok jelenlegi múködését. Vannak, akik az állatok kihasználásával nem értenek egyet, tekintve, hogy az állatok is érző lények. Mások inkább az állattartás jelenlegi körülményeivel nem tudnak azonosulni. A fejlett tejgazdaságok folyamatos technológiai fejlesztésekkel törekednek a tartási körülmények javítására. A robotika fejlődésével lehetőség nyílt arra is, hogy a tehenek stresszmentes módon, saját igényüknek megfelelően vegyék igénybe a fejőrobotok szolgáltatásait is, amikor szükségük van rá, mindezt egy kényelmes, klimatizált környezetben (SZENT ISTVÁN EGYETEM, 2020).

A leírtak alapján ezért több fogyasztó számára elfogadhatóbb alternatívaként jelennek meg az egyes növényekből készült tejhelyettesítő italok, amelyek a tejhez hasonló ízélményt, és egészségügyi előnyöket ígérnek a tejtől elforduló fogyasztók számára (LAASSAL és KALLAS, 2019). A tej, mint termék, valós megítélését nehezíti, hogy a témában készült kutatások is eltérő eredményeket közölnek (SZỨCS, 2019), nem is beszélve arról, hogy a tej és a tejhelyettesítők gyártói is folyamatosan ellentmondásos információkkal „bombázzák” az igencsak összezavarodott fogyasztókat. A továbbiakban tehát arra a kérdésre keressük a választ, hogy vajon milyen változások várhatóak a tejágazatban? Képes-e „azonosulni” a tej, mint termék az átalakulóban lévő fogyasztói igényekkel? Továbbá célunk feltárni a tejjel és helyettesítő termékeivel kapcsolatos fogyasztói attitűdöket is. A tej helyettesítését célzó termékek kapcsán fontosnak tartjuk megjegyezni, hogy tanulmányunk során a jelenlegi, hazai és nemzetközi szakirodalmakban használt elnevezéseket alkalmazzuk (tejhelyettesítő, növényi alapú ital, tej-analóg) egyéni állásfoglalás nélkül, a téma közérthetősége érdekében. 


\section{A TEJIPAR JELENLEGI HELYZETE} - The Current Situation of The DAIRY INDUSTRY

A növényi italok piaci pozíciójának erősödését látva a tejipar igyekezett néhány lépést tenni, annak érdekében, hogy megvédje a piacát. Ennek részekén született meg 2017-ben az az uniós szabályozás is, amely szerint valamilyen emlősre van ahhoz szükség, hogy a végterméket tejnek lehessen hívni (MYLAN et al., 2019; MILBURN, 2018b). Ennek megfelelően a szója-, rizs- és zabtej kifejezések nem helyesek jogilag (ugyanez érvényes a joghurt vagy sajt esetében is). A helyes megnevezés a szója tej helyett a szója ital. Azonban a hazai Tejtermék Tanács nyílt levélben az elnevezések terén további szabályozást kér az Európai Uniótól (TRADEMAGAZIN, 2021). Javaslatuk szerint az Európai Unióban korlátozásra kerülnének azok a kifejezések, amely bármilyen módon utalnak a tejre a növényi alapú „utánzatok” esetében pl. tejhelyettesítő, tejszínízü, sajtszerü, joghurtstílusú termékek, ugyanis ezek a kifejezések félrevezethetik és megtéveszthetik a fogyasztókat. Felmerülhet a kérdés azonban, hogy miután a fogyasztói köztudatban már növényi tejként rögzültek ezek a termékek, vajon ez a szabályozás mennyire éri el a kívánt hatást és érzékelteti a fogyasztókkal a termékek közötti jelentős eltéréseket. Némileg hasonlít a helyzet a vaj és margarin esetére, amikor a fogyasztókat annyira meggyőzték arról, hogy az olcsóbban előállítható margarinnal tökéletesen helyettesíthetik a vajat, hogy míg a margarin fogyasztása megugrott, a vajé visszaesett. Az elnevezés pontosításán túl vajon még mit tehet a tejipar, termékeinek növényi változatától való megkülönböztetése érdekében? Úgy tűnik ugyanis, hogy a növényi tejtermék-helyettesítők piaci részesedése évről évre dinamikus növekedést mutat (McCARTHY et al., 2017)

Míg a 90-es években a vegetarianizmus mögött meghúzódó fő ok az egészséges életmód volt, manapság számos tanulmány alapján inkább az etikai megfontolás dominál (HAAS et al., 2019). Egy 2016. évi felmérés szerint (JANSSEN et al., 2016) a vegán életstílus választása mögött 90\%-ban az állatjólét megvalósításának törekvése állt. Mivel az etikai okokból vegánná válók száma egyre intenzívebben növekszik (ETHICAL CONSUMER, 2018), így érdemes feltárni azokat a tényezőket, amelyek a tejfogyasztás megszüntetésére sarkalhatja a fogyasztókat. A vegán életmódot folytatók elsősorban a nem megfelelő állattartási körülményeket nevezik meg fó oknak, amely az állati tejfogyasztás elutasítása mögött áll (LAASSAL és KALLAS, 2019). A vegetáriánus és vegán fogyasztók életmódja között a fő különbség, hogy míg a vegetáriánusok az étkezésükben kerülik az állati eredetet, addig a vegánok az életük minden területére kiterjesztik azt.

Azoknál a gazdaságoknál, ahol törekednek jobb, etikusabb körülmények biztosítására az állattartás során, gyakran azzal a problémával szembesülnek, hogy nem tudják megfelelően pozícionálni az ily módon előállított tejet. Ugyanis, amíg a tojás és a hús esetében az EU-s címkék információt tudnak nyújtani az állattartási körülményeiről, ezt a tej esetében jelentősen nehezebb kivitelezni. A különböző gazdaságokból begyüjtött tejet ugyanis összekeverik, így a fogyasztó nem tudja nyomon követni, hogy az általa vásárolt végtermék milyen tartási körülmények között élő állattól származik (KOLBE, 2018).

Az elóbbiekben felsorolt tényezóket figyelembe véve megállapíthatjuk, hogy a tejiparnak a jövőben várhatóan újra kell pozícionálnia magát. Mindeddig azért volt nagy nyomás az ágazaton, hogy az egyre növekvő fogyasztást ki tudja szolgálni, ez volt az elsődleges szempont, amelyhez hozzá igazították a termelés feltételeit. Most viszont egy olyan fogyasztói átalakulásnak lehetünk szemtanúi, ahol a vásárlók által képviselt értékek egyre inkább megjelennek a konkrét fogyasztásuk során is. Ennek bizonyításaképpen sok országban megfigyelhető a tejpiac növekedésének megtorpanása, esetlegesen a kereslet visszaesése. Ha megvizsgáljuk a potenciális fogyasztók piacát, akkor láthatjuk, hogy a következő szempontok miatt csökkenhet a tej iránti kereslet (MYLAN et al., 2019):

- a tej elutasítása egészségügyi szempontok alapján (allergia, diéta, termékben megjelenő hormon- és gyógyszermaradványok egészségügyi kockázata);

- a tej elutasítása környezeti szempontból (kisebb ökológiai lábnyommal járó alternatíva); 
- tej elutasítása etikai szempontból (állatjólét).

Az előzőekben már említett innovációs tevékenységek (tejfehérje-allergiások számára is fogyasztható tej, az állatok minél etikusabb tartásának megvalósítása) mellett érdemes lehet kiemelt figyelmet fordítani az ökológiai lábnyom csökkentésére is (víz- és energiafelhasználás csökkentése vagy környezettudatosabb csomagolás megvalósítása pl. növényi alapú műanyag csomagolás használatával). Az ehhez hasonló technikai újítások a későbbiekben jelentős versenyelőnyt jelenthetnek a gyártók számára és hatással lehetnek a csökkenő kereslet megállítására.

A tej piaca ugyanis némiképpen beszúkülni látszik a fejlett országokban, ami elsősorban az alternatív italok, azok közül is föleg a különböző növényekből készült tejhelyettesítő italok előtörésének köszönhető. Kanadában az elmúlt évtizedben közel 22\%-kal csökkent az egy före jutó tejfogyasztás, ezzel szemben az ízesített tejitalok és tejszín fogyasztása nőtt (CONSUMER CORNER, 2016). A globális piacot nézve az Egyesült Államokban és Európában folyamatos csökkenést mutat a tej iránti kereslet (HAAS et al., 2019). Az EU-ban 2008 és 2018 között 6 kgal csökkent az egy főre eső tejfogyasztás $(52 \mathrm{~kg} /$ főre) és 2030-ra várhatóan ez tovább fog csökkenni, $49 \mathrm{~kg} /$ före. Ezzel szemben a növényi alapú italok eladása az utóbbi évtizedben megduplázódott (ETHICAL CONSUMER, 2018). Azonban érdemes megjegyezni, hogy eközben Afrikában, Dél-Ázsiában, Kelet-Ázsiában egy évtized alatt duplájára nőtt a tejfogyasztás (HAAS et al., 2019). A FAO (2016) előrejelzése szerint a globális tejtermelés 2025-re 23\%-kal fog növekedni 2013-hoz képest. A világ régiói közül a tehéntej-fogyasztás az Egyesült Államokban és Európában folyamatosan csökkeni fog, míg más régiókban éppen ellenkezőleg, növekedni fog (ALEXANDRATOS és BRUINSMA, 2012; ZINGONE et al., 2017).

A 2020. évi COVID járvány szintén negatív hatással volt a tejiparra. A tehéntej-fogyasztás és -export is csökkent a járvány kitörése óta, ugyanez igaz a sajt és a vaj exportjára is, ami elsősorban Kína és a Közel Kelet csökkenő keresletének köszönhető. Ez pedig várhatóan a tejtermékek árának további csökkenéséhez vezet majd a világpiacot tekintve (GAIN, 2020).

\section{NÖVÉNY ALAPÚ}

\section{TEJHELYETTESÍTóK - PlaNT-}

\section{BASEd Milk Substitutes}

A növényi alapú italok már az 1950-es évektől léteznek, azonban csak az utóbbi évtizedben váltak igazán népszerűvé (MYLAN et al., 2019). Ezeknél a termékeknél mind a csomagolás, mind a termékkihelyezés a boltokban (többnyire a tehéntej mellett), a termékekkel kapcsolatos gyártói reklámok és maga a termék színe és állománya (állaga) is mind azt sugallják a vásárlók számára, hogy tökéletes helyettesítői a tehéntejnek (LAASSAL és KALLAS, 2019). A növényiital-gyártók marketingkommunikációjának jellemző üzenetei közé tartozik a kategória tehéntejnél egészségesebb (alacsonyabb zsír- és kalóriatartalom) alternatívaként történő pozicionálása. Az egészségvédő jellemzők mellett a környezeti szempontok hangsúlyozásával, mint „zöld” termékek kerülnek kommunikálásra a környezettudatos fogyasztók felé. A szektor piaci pozíciójának erősödését mutatja, hogy az Egyesült Államokban 2012-2017 között 61\%-kal nőtt a növényi alapú italok eladása (MINTEL, 2017a). Ennek eredményeképpen 2017-re a teljes „tej”-eladás 12\%-át már növényi alapú termékek tették ki (GUARDIAN ONLINE, 2018). A növényi alapú tej-analógok piaci pozíciója várhatóan további erősödést mutat majd. Míg az Egyesült Államokban 2016-ban 6 milliárd dollár folyt be ezen termékek eladásából, addig 2021-re 28 milliárd dollárra jósolják ezt a számot (PACKAGED FACTS, 2017). Európára vetítve az eladásokat, míg 2013-ban 1797,38 millió euró volt a teljes piaci eladások összege, addig ez a szám 2018-ra 2765,54 millió euróra nőtt (LAASSAL és KALLAS, 2019).

A növény alapú italokat leginkább az alapanyaguk szerint érdemes csoportosítani. Ez alapján megkülönböztetünk gabona (zab, rizs); hüvelyes (szója, csicseriborsó); mogyoróféle (mandula, brazildió, kesudió, mogyoró), csíra (szezámmag, napraforgómag), álgabona (kinoa) alapú italokat. Európában a legnépszerúbb a szójaital $(70,5 \%)$ ezt követi a mandulatej (14,64\%), majd a rizstej (7,9\%), végül pedig a többi növényi alapú ital (pl. kókusz, zab, stb.) az ágazat eladásainak 6,8\%-át teszi ki (LAASSAL és KALLAS, 2019; SETHI et al., 2016). Fontos megemlíteni, hogy a növényi italok esetén nem 
beszélhetünk egységes tápanyagtartalomról. CHALUPA-KREBZDAK et al. (2018) tanulmánya során 17 fajta növényi italt hasonlítottak össze a tehéntejjel. A felmérésból egyértelmüen kiderült, hogy nem csak a különböző alapanyagok (mandula, szója, kókusz) miatt eltérő a termékek tápanyagtartalma, de az azonos növényből készült italok között is jelentős különbség tapasztalható. Az eredmények arra is rámutattak, hogy jó néhány növényi ital valójában magasabb kalóriatartalommal rendelkezett, mint a 2\%-os tehéntej, amihez átlagosan alacsonyabb fehérjetartalom párosult. A kalciumszint viszont az esetek többségében elérte, sőt meg is haladta a tehéntej szintjét (másrészről viszont néhány márka terméke egyáltalán nem tartalmazott kalciumot). A kalcium kapcsán azonban fontos megjegyezni, hogy a növényi italokból való felszívódása kedvezőtlenebb a tehéntejéhez képest (SZƯCS, 2019).

A piacot vizsgálva megállapítható, hogy a fogyasztókat nem lehet egyértelmüen tehéntej és növényi alapú italvásárlókra bontani. Az Egyesült Államokban tejterméket fogyasztók több, mint fele ugyanis szintén vásárol növényi alapú italokat is (McCARTHY et al., 2017). Hazánkban a lakosság 97\%-a fogyaszt tejet és/ vagy tejterméket, $28 \%$ pedig növényi alapú terméket. Utóbbi szegmenst tekintve azonban csak 3\% azoknak a fogyasztóknak az aránya, akik kizárólagos növényi termék fogyasztónak tekinthetők (STORE INSIDER, 2021a). A növényi analóg fogyasztók demográfiai háttérváltozóit vizsgálva pedig az derül ki, hogy a vásárlók többségét elsősorban a fiatal nők alkotják (MINTEL, 2017b; MINTEL, 2016; HAAS et al., 2019; MYLAN et al., 2019). A növényi italok egyre növekvő népszerűségére a nagyobb cégek is felfigyeltek és úgy döntöttek érdemes belépniük a piacra. Míg a Danone az Alpro nevezetü legnépszerübb növényi italgyártót vásárolta fel, addig a Coca-Cola az AdeZ márkával tette ugyanezt, a Nestlé pedig 60\%-os részesedést szerzett a Yinlu, a világ 5. legnagyobb növényi italt gyártó márka cégcsoportjában (MYLAN et al., 2019).

A következőkben azt vizsgáljuk meg, hogy a növényi italok mennyire tekinthetőek a tehéntej tökéletes helyettesítő termékeinek az egyes élelmiszerjellemzők alapján. Habár kinézetében nagyon hasonló a tehéntejhez, a növényi alapú italoknak más az íze és a textúrája, mint a hagyományos tejnek. Még az egyes italok között is érezhető különbség van attól függően, hogy miből készültek. Leginkább a fehér ital állaga miatt kaphatta meg a „tej” elnevezést a köznyelvben. Az ízélmény eltér az állati eredetű megfelelőjétől, azonban leginkább fogyasztó preferenciától függ a pozitív vagy negatív megítélése az összehasonlítás során. Bár a fogyasztók többsége szerint elmarad az ízélmény a hagyományosan megszokott tejétől - sok fogyasztó „krétásnak” vagy „nyersnek” titulálja (AYDAR et al., 2019; ODURO, 2018). Ezzel szemben egy másik felmérés szerint a növényi italok vásárlásának egyik fő oka, hogy a fogyasztók kedvelik az ízét (MINTEL, 2017b).

A következő vizsgált jellemző az egészségre gyakorolt hatás. A növényi ital pozitív tulajdonságai közé tartozik, hogy laktózmentes, tejfehérjementes, alacsony a telítettzsírsav-tartalma, magas a rosttartalma és izoflavonoidokat is tartalmaz (SILVA et al., 2020). Az Európai fogyasztók 15\%-a kerüli a tehéntejből készült termékeket, egyrészről egészségügyi okokból laktózintolerancia, tejfehérje-allergia, koleszterin problémák - vagy életmódból eredően - vegán étrend, illetve különböző tehéntejjel kapcsolatos fogyasztói félelmek - a tejben fellelhető hormon- és antibiotikum-maradványok - miatt (IFT, 2015; McCARTHY et al., 2017; LAASSAL és KALLAS, 2019). Az előbbiek alapján látható, hogy a tejjel kapcsolatos ételintoleranciában szenvedők számára a növényi italok valóban jó alternatívaként szolgálhatnak, habár érdemes megjegyezni, hogy a mogyorófélék és a szója is beletartoznak a 8 leggyakoribb ételallergiát kiváltó élelmiszer közé (PATEL és VOLCHECK, 2015). Továbbá szintén megjegyzendő, hogy a tejfehérje-allergiában szenvedő fogyasztók 14\%-a szójafehérjére is allergiás (SILVA et al., 2020). Habár számukra más növényből készült ital megoldásként szolgálhat, azonban egyedül a szója rendelkezik hasonló fehérjetartalommal, mint a tehéntej (JESKE et al., 2017). A szója, mint alapanyag más szempontból is megkérdőjelezhető, ugyanis egyes kutatások arra hívták fel a figyelmet, hogy a túlzott szójafogyasztás hormonális zavarokhoz is vezethet bizonyos esetekben (NARDI et al., 2017). A tehéntej helyettesítésének egyik legproblémásabb része a már előbbiekben emlí- 
tett elégséges fehérjebevitel. A felnőtt lakosság ugyanis kizárólag növényi alapú táplálkozás esetében könnyen kerülhet fehérje deficitbe, ami egyértelmúen káros az egészségükre nézve (MÄKINEN et al., 2016; AYDAR et al., 2019). Míg a tej fehérjetartalma 3,28\%, addig a növényi italokban átlagosan ez az arány sokkal alacsonyabb, habár ez erősen függ az ital alapjául szolgáló növénytől. A legmagasabb fehérjetartalommal a szója alapú italok rendelkeznek $(8,71 \%)$, míg a legalacsonyabbal a rizsitalok (0,07\%) (VANGA és RAGHAVAN, 2017).

A növényi italok további hátárnyaként említhető a tehéntejhez képest alacsonyabb a mikrotápanyag-tartalmuk, amihez viszont magas antinutriens tartalom párosul, amely nehezíti a termék emészthetőségét és gátolja a vitaminok és ásványi anyagok felszívódását. Ennek elsődleges oka, hogy a vitaminok és ásványi anyagok biohasznosulásának feltétele a fermentáció (AYDAR et al., 2020). A növényi italok esetében azonban ezeknek a hiánya rontja a tápanyagok felszívódási képességét. Az egyes növényi alapú termékeknél azonban fontos megjegyezni, hogy a különböző alapanyagokból készült végtermék más-más tulajdonságokkal bír (pl. a rizs hipoallergén élelmiszernek számít, így az élelmiszer-intoleranciára hajlamos fogyasztók számára jó helyettesítő lehet, azonban nagyon alacsony a fehérjetartalma; a zab ezzel szemben segíthet a vércukorszint szinten tartásában, vagy a koleszterin csökkentésében, de hátránya, hogy alacsony kalciumtartalommal rendelkezik). Az előzőekben említettek miatt a szakemberek azt javasolják, hogy érdemes váltogatni az egyes termékeket, vagy olyan növényi italokat kell fogyasztani, amibe többféle növényi alapanyag is felhasználásra kerül, ezáltal hasonló tápanyagtartalmat elérve, mint a tehéntej esetében (SILVA et al., 2020).

A növényi italok fogyasztói preferenciáit vizsgálva kiderül, hogy a vásárlást befolyásoló legfontosabb termékjellemzők rangsorolva a következők: alacsony cukortartalom, az ital alapanyagául szolgáló növény típusa és a csomagolás mérete. Összehasonlításképpen a tehéntejvásárlást leginkább befolyásoló tényezők a következők: zsírtartalom, a kiszerelés és a védjegyek, pl. hazai (McCARTHY et al., 2017). Úgy tünik, míg a növényi italoknál a cukortartalom a legfontosabb a fogyasztók számára, ad- dig a tehéntej esetében ez a tényező a zsírtartalom. A növényi italokkal szemben a leginkább elvárt termékelőnyök a testtömeg-kontroll segítése, hormonmentes végtermék, könnyú emészthetőség, természetesség és organikusság. Továbbá a fogyasztók preferálják azokat a növényi italokat, amelyek a tehéntejhez hasonló (hozzáadott) vitamin-, (hozzáadott) kalcium- és fehérjetartalommal rendelkeznek (McCARTHY et al., 2017; LAASSAL és KALLAS, 2019). Megjegyzendő, hogy a fogyasztói tudatosság és tájékozottság hiányában a növényi ital fogyasztása nem feltétlenül egészségvédő hatású, könnyen kialakulhat tápanyaghiányos állapot (SZÚCS, 2019; SCHMIDT, 2019), ugyanis a növényi termékre való átállás a fogyasztók többségénél csökkenti a kalcium, a fehérjék, az ásványi anyagok és számos vitamin bevitelét, míg a sóét növeli (SOUSA és BOLANZ, 2017). Továbbá a gyerekek és várandósok esetében fokozott tudatosságra és odafigyelésre van szükség (SCHMIDT, 2019; CHALUPA-KREBZDAK et al., 2018). Gyermekkorban a nem megfelelő tejmentes étkezésnek számos egészségügyi kockázata lehet, például egy felmérés alapján azok a 3 évesek, akik napi 3 pohár növényi tejhelyettesítőt fogyasztottak átlagosan $1,5 \mathrm{~cm}$ rel voltak alacsonyabbak, mint a tehéntejet fogyasztó társaik (MORENCY et al., 2017). A kockázatok ismeretében megfontolandó, hogy a gyermekek számára mennyire jelent jó alternatívát a tej helyett az egyes növényi italok fogyasztása.

Ahogy az előzőekből is látható növényi italok piaca intenzív növekedést mutatott az elmúlt években és ez a tendencia hazánkban is egyre inkább érezhetővé válik a növényi italt gyártó márkák (pl. Alpro, AdeZ, Joya) termékeinek megjelenésével. Emiatt úgy gondoljuk érdemes magyar viszonylatból is megvizsgálni a növényi italok piacát.

A Copa-Cogeca - az Európai Gazdálkodók és Európai Termelőszövetkezetek - és társszervezetei 2020 őszén nyílt levelet tettek közzé, „Hívjuk az ásót ásónak!” címmel (STORE INSIDER, 2021b). A javaslatban foglaltakon túl továbbra is célnak tartják, hogy a jövőben semmilyen módon ne lehessen megtéveszteni a fogyasztókat. Az olyan növényi alapú tejtermék utánzatok, mint például a „cheddar/parmezán/gouda ízű növényi tömb”, a „mylk”, a „va- 
jas ízű margarin” vagy a „szójagurt” elnevezései a javaslat szerint egyértelműen megtévesztik a fogyasztókat. Habár az Európai Parlament és az Európai Tanács - állati eredetű élelmiszerek különleges higiéniai szabályainak megállapításáról szóló - 853/2004/EK rendeletének 1. melléklete egyértelműen rögzíti a hús, a tej, valamint a húskészítmények és tejtermékek fogalmát, addig a növényi alapú utánzatok elnevezései még nem teljes körűen tisztázottak. A szervezetek tiszteletben tartják az európai fogyasztók egy szúkebb szegmensének azon igényét, hogy a növényi alapú, hús- és tejmentes, illetve ezen termékek pótlására szolgáló (vegetáriánus/vegán) termékek aránya növekedjen. Azonban tisztességes és következetes marketingtevékenységet várnak el Európában. Olyan szabályozást, amely tiszteletben tartja a hús- és tejtermék-fogyasztók, valamint a vegetáriánus/ vegán vásárlók igényeit is, továbbá tiszteletben tartja a mezőgazdasági termelők, valamint a hús- és tejipar által végzett munkát (STORE INSIDER, 2021b). Mindeközben a Baromfi Termék Tanács, a Hússzövetség, a Magyar Állattenyésztők Szövetsége, a Nemzeti Agrárgazdasági Kamara, a Tej Terméktanács, valamint a Vágóállat és Hús Szakmaközi Szervezet és Terméktanács határozottan felszólal azért, hogy az Európai Unió ne engedje az élelmiszerek megtévesztő elnevezését (TRADEMAGAZIN, 2021). A 171-es számú módosító javaslat az egész Európai Unióban korlátozná az olyan kifejezések használatát, mint: „joghurt (vagy túró) stílusú”, „sajtutánzat”, „tejszín ízű”, „laktózmentes tejhelyettesítő”, „sajtszerü”, és minden összefüggésben megtiltaná a tejet nem tartalmazó áruknál a tej/tejtermék név használatát.

\section{HAZAi NÖvÉNYi ITAL PIAC - Local Market of the Plant- BASEd BEVERAges}

Habár hazánkban is érezhetően egyre népszerübbé válik a növényi italok fogyasztása, tudomásunk szerint egyelöre csak kevés olyan magyar gyártó van, amely hazai alapanyagból gyártana hazai márkájú növényi italt. Pedig hazai alapanyag (rizs, zab, szója) a kisipari gyár- táshoz biztosítható lenne (MAGYAR SZÓJA, 2020; AGRÁRSZEKTOR, 2020a). Mindemellett a tejhelyettesítők piaca egyre inkább kiszélesedik, tejföl, joghurt, sajtok helyettesítésére szolgáló termékek jelennek meg sorra a boltok polcain. Van azonban olyan magyar tejüzem (FINO-FOOD Kft.), ahol kifejlesztettek vegán túróhelyettesítőt, amivel elnyerték 2021-ben a Gulfood hivatalos innovációs versenyén a tejmentes termékek kategóriában a „Leginnovatívabb tejtermék” címet (AGRÁRSZEKTOR, 2021). A magyar Tej Terméktanács által végzett kutatás alapján kiderült, hogy a növényi termékek fogyasztása mögött álló legfontosabb motivációk között szerepel az egészséges életmódra és táplálkozásra való törekvés, a változatos étkezés igénye, a fenntartható fogyasztás megvalósítása és a különböző tejjel kapcsolatos érzékenységek megléte (STORE INSIDER, 2021a).

Példaként megvizsgáltuk a svéd Oatly's növényi italokat gyártó cég marketingkommunikációját (OATLY, 2019). Az Oatly’s úgy pozícionálja magát, mint vegán, fenntartható, egészséges, kisipari és hazai termékeket gyártó cég (FUENTES és FUENTES, 2017). Az Oatly's esetében nagyon fontos hangsúlyt kap az értékalapú marketingkommunikáció, amely során a cég jól meghatározható értékcsoportokat ragad meg és építi be a fogyasztók felé intézett üzeneteibe. Az Oatly's marketingkommunikációjában általunk azonosított értékcsoportok nagyon is hasonlítanak a bevezetőben már említett LOHAS, fenntarthatóság mellett elkötelezett, fogyasztói csoport által képviselt értékekhez. Úgy pozícionálják a terméküket, mint a tehéntej környezet- és egészségtudatos alternatívája, amely teljes mértékben megvalósítja az állatjóléti szempontokat is (etikusság). Emellett pedig az autentikus értékek is megjelennek esetükben, a helyi alapanyagok használatának hangsúlyozásával és a „Svéd” termékcímke feltüntetésével. A márka termékeinek fogyasztása egy tudatosan választott életstílust képvisel (individualizmus megjelenése) (FUENTES és FUENTES, 2017).

Az Oatly's marketingstratégiájának alapja az erős közösségépítés, a személyes hangvételű üzenetek, az értékalapú kommunikáció és a már-már sokszor provokatív figyelemfelkeltés. A cég kommunikációjában a fogyasztói vissza- 
csatolásnak is fontos szerepe van, a Facebook és az Instagram felületükön is folyamatos a kommentelőkkel történő párbeszéd, megfigyelhető továbbá a fogyasztók aktív bevonása is (pl. segítséget kérnek egy-egy szlogen választáshoz, új termék elnevezéséhez vagy valamilyen fenntarthatósággal kapcsolatos kérdés megvitatására invitálják a követőiket).

$\mathrm{Az}$ előzőekben bemutatásra kerültek a tejipar helyzetének jelenlegi tendenciái, illetve az elsődleges helyettesítő termékeként megjelenő növényi italok piaci helyzetének jellemzése. Felmerülhet bennünk a kérdés, hogy vajon csak a növényi ital lenne az egyetlen helyettesítő terméke a tejnek? A következőkben néhány példán keresztül mutatjuk be a piaci megjelenésre váró további alternatívákat.

\section{TOVÁBBI TEJHELYETTESÍTó MEGOLDÁSOK - ADDITIONAL SOluTiONS FOR Milk SUbSTITUTE}

\subsection{Tiszta tej - Clean Milk}

A tiszta tej elnevezés alatt egy tehén nélküli, technológiai eszközökkel előállított tejet értünk. Az előállítás során cél a tejtermék molekuláris szinten történő helyettesítése (MILBURN, 2018a). Másik megfogalmazás szerint a tiszta tej olyan tejtermék, amelyet tehenek „bevonása" nélkül biotechnológiai úton állítanak elő (MILBURN, 2018b). A tiszta vagy más néven labortej jelenleg még fejlesztés alatt álló termék. Előállítása során egy élesztő kerül felhasználásra, amely a tehén DNS-ének segítségével kerül módosításra. A módszer előnye, hogy a termék előállítása során a tehén nem kerül „bevonásra”, helyette az élesztő, némi víz és növényi cukrok felhasználásával készül el a végtermék. A tiszta tej elnevezés pedig onnan ered, hogy a termék előállításának laboratóriumi körülményei miatt, a végtermék nem tartalmaz antibiotikum- és hormonmaradványokat, emellett nincs benne koleszterin, laktóz és baktérium sem (PERFECT DAY, 2020). A tiszta tej további érdekessége, hogy kecske, bárány, teve, sőt még anyatejhez hasonló végterméket is elő lehet állítani, attól függően, hogy az élesztő milyen DNS-sel kerül módosításra (MILBURN, 2018b).
A termékkel elsőként a Perfect Day cégcsoport foglalkozott. A termék előnye, hogy míg a növényi italok másféle ízzel és textúrával rendelkeznek, mint a tehéntej, addig a tiszta tej a gyártó ígérete szerint ízélményt tekintve is megfelelő helyettesítője lehet az alapterméknek. Az új termék kapcsán talán a legnagyobb dilemma - és fogyasztói oldalról vizsgálva a legfontosabb kérdés -, hogy vajon mennyire tekinthető természetesnek és egészségesnek? A termék előállítása során alkalmaznak genetikai módosítást, mikor az élesztőt módosítják az állat DNS-ével. Azonban az élesztő nem, csak az általa előállított protein kerül bele a végtermékbe (PERFECT DAY, 2020). A víz és az élesztők által előállított fehérjekeverékhez ezt követően hozzáadják a növényi-alapú zsírokat, cukrokat és tápanyagokat. Ezáltal a tejhez hasonló tápanyag- és fehérjetartalmú végtermék jön létre, ami azonban vegán termék jelöléssel kerül majd a boltok polcaira. Az élesztőn alkalmazott genetikai módosítás a termék előállítása során egy szigorúan zárt és ellenőrzött környezetben történik, így garantálva a termékbiztonságot. Azonban fontos kérdés lehet, hogy vajon a fogyasztók a laboratóriumi körülmények között előállított tiszta tejet mennyire érzik majd „természetellenesnek” vagy „münek”.

További kérdésként merülhet fel, hogy vajon azon fogyasztóknál, akik elsőre természetellenesnek tartják a terméket, több információ birtokában, az előállítás érthető szemléltetésével (a sör előállításához hasonlítva) megváltozható lenne-e a véleményük. A tiszta tejhez használt erjesztési technikát ugyanis a kézműves sörök előállítása során több mint 3 évtizede használják (LEVITT, 2016). Szintén érdekes kérdés lehet, hogy azok a vegán étrendet folytató fogyasztók, akik eddig elsősorban állatjóléti szempontok alapján utasították el a tehéntejet, vajon hogyan vélekednének erről a termékről.

Mielőtt a tiszta tejre valódi helyettesítő termékként kezdünk el tekinteni, úgy gondoljuk az előbb említett számos kérdés alapján, hogy a jövőben szükséges lenne egy fogyasztói attitűd vizsgálatot elvégezni, ahol feltárásra kerülne a fogyasztói elfogadás mértéke, korlátai, preferenciái. Fontos azonban megjegyezni, hogy a tejfehérje-allergiás fogyasztók számára a tiszta tejben található fehérje - amennyiben tehén DNS segítségével kerül előállításra - továbbra 
is allergénként jelenik meg (PERFECT DAY, 2020).

Az előzőek alapján látható, hogy egy új termékkategória bevezetése számos szempontból vet fel kérdéseket és problémákat, másfelől azonban potenciális alternatívája lehet a tehéntejnek, amire a tejiparnak is oda kell figyelnie.

\subsection{Fejlesztés alatt álló tejhelyettesítók - Milk Substitutes Under Development}

A növényi alapú tejhelyettesítésen és a tiszta tejen kívül további új innovációs törekvések is vannak a tehéntej kiváltására. A Szent István Egyetem Mezőgazdaság- és Környezettudományi Karának kutatói tojásalapú tejtermék-helyettesítő élelmiszerek kifejlesztését tüzték ki célul (AGRÁRSZEKTOR, 2020b). A koncepció abból indul ki, hogy sok fogyasztó számára a tej és tejtermékek fontosak, ugyanakkor különböző okokból (tejcukorérzékenység, tejfehérje-allergia, paleo étrend) kerülik azokat. Erre az igényre jelenthetnek megoldást a tojásfehérje alapú tejtermék-helyettesítő termékcsalád készítményei (pl. probiotikus fermentált ital, sajtkrém, kefir- és joghurt-analógok).

Egy másik lehetőség a tejhelyettesítésre a tiszta tejhez hasonlóan, a laboratóriumi körülmények között előállított mesterséges „tej”. Egyes start-up cégek már kísérleteznek azzal, hogy nyerstejet állítsanak elő emlősökből származó őssejtek kontrollált, in-vitro laboratóriumi körülmények közötti szaporításával. Az emlős őssejteket áthelyezik egy olyan környezetbe, ahol emlőmirigy-sejtekké alakulnak. Az emlőmirigy-sejtek kölcsönhatásba lépnek egy speciális tápszerrel (táptalajjal), amely kiváltja a sejtek laktációját, tejtermelését. A végterméket szürési eljárással kapják meg (TURTLETREELABS.COM).

Mint az előzőek alapján is látható a jövőben várhatóan több alternatív termék is megjelenhet a piacon, azonban, hogy melyik válhat valódi helyettesítő termékké az leginkább a fogyasztói elfogadás mértékétől függ majd.

\section{7. ÖSSZEFOGLALÁS - SUMMARY}

Munkánk során megvizsgáltuk a tejipar jelenlegi helyzetét és főbb kihívásait, majd a jelenleg elsőszámú helyettesítő termékének - a növényi helyettesítő italoknak - a piaci helyzetét és fogyasztói attitűdjeit tanulmányoztuk át. Végül pedig egy új helyettesítő termék, a tiszta tej bemutatására került sor, illetve megemlítésre került néhány fejlesztés alatt álló tejtermék-helyettesítő is (tojás alapú tejtermék-helyettesítő, mesterséges „tej”).

Vizsgálatunk eredményeiból megállapítottuk, hogy a tehéntej továbbra is alapvető szerepet tölt be az emberek táplálkozásában, azonban számos kihívással néz szembe. Ezek a kihívások pedig a piaci részesedésére is hatással lehetnek. A jelenlegi tendenciákat látva úgy tünik, hogy bizonyos fogyasztói csoportok körében várhatóan tovább nő azok száma, akik valamilyen okból - egészségügyi, etikai, környezeti - felhagynak a tehéntej fogyasztásával és növényi alapú helyettesítő termékeket részesítenek majd előnyben. Ennek ellenére a tejiparnak is jó lehetőségei vannak.

Az amerikai fogyasztók 67\%-a tekinti a tejet természetesen tápláló terméknek, szemben az alternatív „tejekkel”, ahol ez az arány csak $60 \%$. További előny a fogyasztók szerint a tej adalékanyag-mentessége az alternatív helyettesítőkkel szemben ( $81 \%$ vs. 62\% gondolja így), továbbá frissessége, amit az amerikaiak $86 \%$-a gondol a tejról, míg ugyanezt csak 63\%-uk véli a tejalternatívákról (MINTEL GROUP, 2016). További előny a tejtermékek kiváló élvezeti értéke, amiről az amerikai fogyasztók 82\%-a nyilatkozott pozitívan, míg a tejhelyettesítő italoknál ez az arány csak 61\% volt (MINTEL GROUP, 2016). A tej hazai megítélése is kedvező. A magyar fogyasztók kétharmada egyetért azzal, hogy a tej és tejtermékek nélkülözhetetlenek az egészséges táplálkozás szempontjából, az emberi szervezetnek minden életkorban szüksége van ezekre a finom és tápláló termékekre (STORE INSIDER, 2021a). Mindezek alapján a tejtermékek piaci pozicionálásakor célszerü hangsúlyozni a kiváló élvezeti értéket és a természetesen tápláló és egészséges jellemzőket (MINTEL GROUP, 2016), kiemelten azokat, amelyeket a növényi italok továbbra sem tudnak pótolni. Továbbá fontos felhívni a lakosság figyelmét az elégtelen tejfogyasztás következményeképpen kialakuló betegségekre is (pl. csontritkulás).

Habár a tejipar mozgástere sok szempont- 
ból korlátozott, azonban egyfajta átalakulás mindenképpen szükségesnek látszik. A jelenlegi fogyasztói attitűdök alapján a környezeti fenntarthatóságra való törekvés és az állatjólét legmagasabb szintű megvalósítása alapvető elvárássá válhat a piaci pozíció megtartása érdekében. Az innovációs törekvések további versenyelőnyhöz juttathatják az ágazatot, ami megjelenhet a termék (pl. tejfehérje-allergia megoldása), vagy az előállítás (pl. víz- és energiafelhasználás csökkentése) vagy az állattartás (pl. jobb tartási körülmények) kapcsán. Tanulmányunk során mindhárom terület esetében említésre kerültek hazai innovációs tevékenységek is.

A növényi italok piaca várhatóan tovább bővül, az évről évre folyamatosan szélesedő termékskálájuk egyre vonzóbbá teszi a fogyasztók számára a növényi alapú termékekre történő átállást. A még teljesebb ízélmény és a tejhez hasonló tápanyagtartalom megvalósítása a két fó kihívás, amelyet a fogyasztók elvárnak az ágazattal szemben. A növényi termékek piaca még közel sem telített, de érezhető egy egyre élesedő verseny, ahol leginkább az árral és a márkanévvel tudnak versenyezni a vállalatok. A fogyasztók fóbb elvárásai a növényi alapú helyettesítőkkel szemben: legyen hazai márka, fontos az eredeti, természetes íz, ne tartalmazzon hozzáadott cukrot, továbbá legyen a termék vitaminokkal és kalciummal dúsítva, miközben nélkülözze a különböző ízesítések és adalékanyagok használatát (McCARTHY et al., 2017; LASSAL és KAALLAS, 2019).

A tiszta tej, mint új technológiával előállított termék kapcsán számos kérdés merül fel, fóleg a fogyasztói elfogadás hajlandóságával kapcsolatban. Ennek ellenére a tejiparnak érdemes figyelemmel követnie a várhatóan hamarosan piacra lépő új termékeket. Javaslataink között szerepel az egyes tejtermék-analógok kapcsán egy, a helyettesíthetőség mértékét vizsgáló kutatás lebonyolítása, amely választ adhatna a tejipar számára arra a kérdésre, hogy termékeik kiváltását célzó készítmények a fogyasztói megítélés alapján valójában mennyire tekinthetőek valós „tejtermék pótlóknak”.
Összefoglalásképpen, a tejipar pozíciója a jövőben várhatóan megváltozik, piaca átalakul, és a mennyiségi ellátás mellett megjelenik az igény a megkülönböztető minőség iránt. A tehéntej újrapozícionálása elengedhetetlen, de egyúttal új lehetőséget teremt a tejipar számára, hogy kisebb mennyiségben és még jobb minőségben tudnak termékeket előállítani fenntartható módon. Az így előállított termék várhatóan a fogyasztók számára is magasabb értéket fog képviselni, amely feltételezhetően a termékek fogyasztói árában is tükröződni fog.

\section{KöSZÖNETNYILVÁNÍTÁs -}

\section{ACKNOWLEDGEMENTS}

A cikk elkészítését a GINOP-2.3.2-15-2016-00062 számú projekt támogatta. A projekt az Európai Unió támogatásával, az Európai Regionális Fejlesztési Alap társfinanszírozásával valósult meg.

\section{IRODALOMJEGYZÉK - REFERENCES}

Alexandratos, N. - Bruinsma, J.: World Agriculture Towards 2030/2050. ESA Working Paper No. 12-03. 2012. URL: http://www.fao.org/3/a-ap106e.pdf (Letöltés dátuma: 2020.10.12.)

Agrárszektor: Hihetetlenül sikeres a magyar rizs: aki megkóstolta, már csak ezt akarja enni. 2020a. URL: https://www. agrarszektor.hu/noveny/hihetetlenulsikeres-a-magyar-rizs-aki-megkostoltamar-csak-ezt-akarja-enni.22296.html (Letöltés dátuma: 2021.02.17.)

Agrárszektor: Szokatlan alapanyagból készül tejhelyettesítő Magyarországon: te megkóstolnád? 2020b. URL: https://www. agrarszektor.hu/elemiszer/szokatlanalapanyagbol-keszul-tejhelyettesitomagyarorszagon-te-megkostolnad.25318. html?utm_source=agrarszektor\&utm medium=email\&utm_campaign=hirlevel (Letöltés dátuma: 2020.10.14.) 
Agrárszektor: Tényleg megoldás a tehenek számüzése? Évtizedes tévhitet cáfolt meg a magyar tudós. 2020c. URL: https://www. agrarszektor.hu/allat/tenyleg-megoldasa-tehenek-szamuzese-evtizedes-tevhitetcafolt-meg-a-magyar-tudos.25328. html?utm_source=agrarszektor\&utm_ medium=email\&utm_campaign $=$ hirlevel (Letöltés dátuma: 2020.10.15.)

Agrárszektor: Magyar részvétellel nyílt meg a világhírü élelmiszeripari esemény. 2021. URL: https://www.agrarszektor. $\mathrm{hu} /$ elemiszer/magyar-reszvetellelnyilt-meg-a-vilaghiru-elelmiszeripariesemeny.28144.html (Letöltés dátuma: 2021.02.24.)

Agro Jeger: „Szupertejet” találtak debreceni kutatók. 2021. URL: https://agrojager. hu/tudomany/2021/o1/13/szupertejettalaltak-dereceni-kutatok/ (Letöltés: 2021.02.24.)

Aydar, E. F. - Tutuncu, S. - Ozcelik, B.: Plant-Based Milk Substitutes: Bioactive Compounds, Conventional and Novel Processes, Bioavailability Studies and Health Effects. Journal of Functional Foods. 2020. 70 103975. DOI: https://doi. org/10.1016/j.jff.2020.103975

Balogh, P.: A tejágazat helyzete, különös tekintettel a tej és tejtermék-fogyasztás a alakulására. Élelmiszer, táplálkozás és marketing. 2016. 12 (2) 29-38.

Balsa-Budai, N. - Szakály, Z.: A fenntartható értékrend vizsgálata a debreceni egyetemisták körében. Táplálkozásmarketing. 2018. 5 (1) 3-20. DOI: https://doi.org/10.20494/TM/5/1/1

Balsa-Budai, N. - Kiss, M. - Kovács, B. - Szakály, Z.: Attitudes of Voluntary Simplifier University Students in Hungary. Sustainability. 2019. 11 1802. DOI: https:// doi.org/10.3390/su11061802

Chalupa-Krebzdak, S. - Long, C. J. Bohrer, B. M.: Nutrient Density and Nutritional Value of Milk and Plant-Based Milk Alternatives. International Dairy Journal. 2018. 87 84-92. https://doi. org/10.1016/j.idairyj.2018.07.018
Consumer Corner: Demand for Dairy Milk and Milk Alternatives. 2016. URL: https:// open.alberta.ca/dataset/b5d936eb2127-424e-b1b8-818c486d12aa/ resource/6eac6179-13e1-40fa-a7668803 eea 95 e 29 / download/ 2016 o 9-consumer-corner-is s u e- 38 september-2016.pdf (Letöltés dátuma: 2021.02.14.)

Ethical Consumer: Markets Report. 2018. URL: https://www.askfood.eu/ tools/ forecast/wp-content/uploads/2019/o8/ EC-Markets-Report-2018-FINAL.pdf (Letöltés dátuma: 2020.12.02.)

Fuentes, C. - Fuentes, M.: Making a Market for Alternatives: Marketing Devices and the Qualification of a Vegan Milk Substitute. Journal of Marketing Management. 2017. 33 (7-8) 529-555. DOI: https://doi. org/10.1080/0267257X.2017.1328456

Gain: Dairy and Products Semi-annual, 2020, URL: https://apps.fas.usda. gov / newgainapi / a pi / Report / DowDairy and Products SemiannualnloadReportByFileName? fileName $=\quad$ Dairy\%20and\%20 Products\%2oSemi-annual_Warsaw_ European\%20Union__o5-15-2020 (Letöltés dátuma: 2021.02.14.)

Guardian online: Why Everything You Know About Sustainable Eating Is Probably Wrong. 2018. URL: https://www. theguardian.com/ food/2018/sep/05/ ditch-the-almond-milk-why-everythingyou-know-about-sustainable-eatingis-probably-wrong. (Letöltés dátuma: 2021.02.14.)

Haas, R. - Schnepps, A. - Pichler, A. - Meixner, O.: Cow Milk versus PlantBased Milk Substitutes: A Comparison of Product Image and Motivational Structure of Consumption. Sustainability 2019. 11 5046. DOI: https://doi.org/10.3390/ su11185046

IFT: Dairy-Free Beverages Expand the Milk Aisle. 2015. URL: https://www.newswise. com/articles/dairy-free-beveragesexpand-the-milk-aisle. (Letöltés dátuma: 2021.02.14.) 
Janssen, M. - Busch, C. - Rödiger, M. - Hamm, U.: Motives of Consumers Following a Vegan Diet and Their Attitudes Towards Animal Agriculture. Appetite. 2016. 105 643-651. DOI: https://doi. org/10.1016/j.appet.2016.06.039

Jeske, S. - Zannini, E. - Arendt, E. K.: Evaluation of Physicochemical and Glycaemic Properties of Commercial Plant-Based Milk Substitutes. Plant Foods for Human Nutrition. 2017. 72 (1) 26-33. DOI: https://doi.org/10.1007/s11130-0160583-0.

Kolbe, K.: Why Milk Consumption is the Bigger Problem: Ethical Implications and Deaths per Calorie Created of Milk Compared to Meat Production. Journal of Agricultural and Environmental Ethics. 2018. 31 DOI: https://doi.org/10.1007/ s10806-018-9740-9.

Laassal, M. - Kallas, Z.: Consumers Preferences for Dairy-Alternative Beverage Using Home-Scan Data in Catalonia. Beverages. 2019. 5 (3) 55. DOI: https:// doi.org/10.3390/beverages5030055

Levitt, T.: Animal-Free Dairy Products Move a Step Closer to Market. The Guardian. 2016. URL: https://www.theguardian. com/environment/2016/sep/13/animalfree-dairy-products-move-a-step-closerto-market (Letöltés dátuma: 2021.02.14.)

Magyar Szója: Mi lesz veled, szójabab? A Glencore Agriculture beszámolója a termény hazai helyzetéról. 2020. URL: https://magyarszoja.hu/mi-leszveled-szojabab/?fbclid=IwARo4pvTA 8O2cCJOQ6NC1slNYUPQENGxje4_ Ujo03SD_O8OdtyrCPT17X5SI (Letöltés: 2021.02.17.)

Mäkinen, O. E. - Wanhalinna, V. Zannini, E. - Arendt, E. K.: Foods for Special Dietary Needs: Non-Dairy PlantBased Milk Substitutes and Fermented Dairy-Type Products. Food Science and Nutrition. 2016. 56 (3) 339-349. DOI: https://doi.org/10.1080/10408398.2012. 761950
McCarthy, K. S. - Parker, M. Ameerally, A. - Drake, S. L. - Drake, M. A.: Drivers of Choice for Fluid Milk Versus Plant-Based Alternatives: What Are Consumer Perceptions of Fluid Milk? Journal of Dairy Science. 2017. 100 (8) 6125-6138. DOI: https://doi.org/10.3168/ jds.2016-12519

MDOSZ: OKOSTÁNYÉR@. 2016. URL: http://www.okostanyer.hu/ (Letöltés dátuma: 2021.02.14.)

Milburn, J.: Clean Milk. In: Thompson, P. - Kaplan, D.: Encyclopedia of Food and Agricultural Ethics. 2018a. Springer, Dordrecht. DOI: https://doi. org/10.1007/978-94-007-6167-4_598-1

Milburn, J.: Death-Free Dairy? The Ethics of Clean Milk. Journal of Agricultural and Environmental Ethics. 2018b. 31 261-279. DOI: https://doi.org/10.1007/s10806018-9723-X

Mintel: US Sales of Dairy Milk Turn Sour As Non-dairy Milk Sales Grow in 2015. 2016. URL: https://www.mintel.com/ press-centre/food-and-drink/us-sales-ofdairy-milk-turn-sour-as-non-dairy-milksales-grow-9-in-2015 (Letöltés dátuma: 2020.10.12.)

Mintel: US Non-Dairy Milk Sales Grow 61\% Over the Last Five Years. 2017a. URL: https://www.mintel.com/press-centre/ food-and-drink/us-non-dairy-milk-salesgrow-61-over-the-last-five-years (Letöltés dátuma: 2020.10.12.)

Mintel: Taste is the Top Reason US Consumers Eat Plant-Based Proteins. 2017b. URL: https://www.mintel.com/press-centre/ food-and-drink/taste-is-the-top-reasonus-consumers-eat-plant-based-proteins

Morency, M. E. - Birken, C. S. - Lebovic, G. - Chen, Y. - L'Abbé, M. - Lee, G. J. - Maguire, J. L.: TARGet Kids! Collaboration. Association between Noncow Milk Beverage Consumption and Childhood Height. The American Journal of Clinical Nutrition. 2017. 106 (2) 597-602. DOI: https://doi.org/10.3945/ ajcn.117.156877. 
Mylan, J. - Morris, C. - Beech, E. Geels, F. W.: Rage Against the Regime: Niche-Regime Interactions in the Societal Embedding of Plant-Based Milk. Environmental Innovation and Societal Transitions. 2019. 31 (233-247) DOI: https://doi.org/10.1016/j.eist.2018.11.001

Naranjo, A. - Johnson, A. - Rossow, H. - Kebreab, E.: Greenhouse Gas, Water, and Land Footprint Per Unit of Production of the California Dairy Industry Over 50 Years. Journal of Dairy Science. 2020. 103 (4) 3760-3773. DOI: https://doi. org/10.3168/jds.2019-16576.

Narcity.hu: Canada's New 2019 Food Guide Cuts Out Milk And Cheese Almost Entirely. 2019. URL: https://www.narcity.com/enca/news/canadas-new-2019-food-guidecuts-out-milk-and-cheese-almost-entirely (Letöltés dátuma: 2020.10.12.)

Nardi, J. - Bonamigo Moras, P. Koeppe, C. - Dallegrave, E. - Bainy Leal, M. - Grazziotin RossatoGrando, L.: Prepubertal Subchronic Exposure to Soy Milk and Glyphosate Leads to Endocrine Disruption. Food and Chemical Toxicology. 2017. 100 247-252. DOI: https://doi.org/10.1016/j. fct.2016.12.030.

Noya, I. - González-García, S. - Berzosa, J. - Baucells, F. - Feijoo, G. Moreira, M. T.: Environmental and Water Sustainability of Milk Production in Northeast Spain. Science of The Total Environment. 2018. 616-617 13171329. DOI: https://doi.org/10.1016/j. scitotenv.2017.10.186.

Oduro, A. F.: Optimization and Characterisation of a 3-Blend Plant Milk Beverage. 2018. Doctoral dissertation, University of Ghana, Legon, Ghana

Oatly: Sustainability Report 2019. URL: https://sustainability.oatly.com (Letöltés dátuma: 2021.02.17.)

Patel, B. Y. - Volcheck, G. W.: Food allergy: Common Causes, Diagnosis, and Treatment. Mayo Clinic Proceedings. 2015. 90 (10) 1411-1419. DOI: https://doi. org/10.1016/j.mayocp.2015.07.012
Packaged Facts: Dairy and Dairy Alternative Beverage Trends in the U.S., 4th Edition: Market Research Report, Packaged Facts. 2017. URL: https://www. packagedfacts. com/Dairy-Alternative-BeverageTrendsEdition-11000293/ (Letöltés dátuma: 2021.02.14.)

Perfect Day: FAQ. 2020. URL: http://www. perfectdayfoods.com/faq/. (Letöltés dátuma: 2021.02.14.)

Pribila, B. A. - Hertzler, S. R. - Martin, B. R. - Weaver, C. M. - Savaiano, D. A.: Improved Lactose Digestion and Intolerance Among African-American Adolescent Girls Fed a Dairy-Rich Diet. Journal of the American Dietetic Association. 2000. 100 (5) 524-528. DOI: https://doi.org/10.1016/Sooo28223(00)00162-0.

Schmidt, J.: Vegetáriánus étrend anyaként és gyermekként - kockázatok és mellékhatások a táplálkozástudomány tekintetében. Magyar Tudomány. 2019. 180 (5) 700-709. DOI: https://doi. org/10.1556/2065.180.2019.5.9

Sethi, S. - Tyagi, S. K. - Anurag, R. K.: Plant-Based MilkAlternatives an Emerging Segment of Functional Beverages: A Review. Journal of Food Science and Technology. 2016. 53 (9) 3408-3423. DOI: https://doi.org/10.1007/s13197016-2328-3.

Silva, A. R. A. - Silva, M. M. N. - Ribeiro, B. D.: Health Issues and Technological Aspects of Plant-Based Alternative Milk. Food Research International. 2020. 131 108972. DOI: https://doi.org/10.1016/j. foodres.2019.108972.

Sousa, A. - Bolanz, K. A. K.: Nutritional Implications of an Increasing Consumption of Non-Dairy Plant-Based Beverages Instead of Cow's Milk in Switzerland. Advances in Dairy Research. 2017. 5 (4) 2. DOI: https://doi.org/10.4172/2329888X.1000197 
Store Insider: A Tej Terméktanács kutatása a növényi alapú italokról. 2021a. URL: http://storeinsider.hu/kereskedo/ cikk/a_termektanacs_kutatasa_a_ novenyi_alapu_italokrol?utm_ source $=$ newsletter\&utm_medium $=$ store in si d e r_n a pi_ h i r level \& u t m _ campaign $=\mathbf{2} 9878$ (Letöltés dátuma: 2021.03.18.)

Store Insider: Vita az élelmiszerek elnevezése körül. 2021b. URL: http:// storeinsider.hu/kereskedo/cikk/ hazai_szervezetek_szolalnak_fel_az_ elelmiszerek_megteveszto_elnevezese_ ellen?utm_source $=$ newsletter\&utm medium = s tore insider $_{-}$to p hirlevel\&utm_campaign=29965 (Letöltés dátuma: 2021.03.29.)

Szakály, Z - Popp, J. - Kontor, E. Kovács, S. - Pető, K. - Jasák, H.: Attitudes of the Lifestyle of Health and Sustainability Segment in Hungary. Sustainability. 2017. 9 (10) 1763. DOI: https://doi.org/10.339o/su9101763

Szent István Egyetem: Vízágyas matracokon pihenhetnek a Szent István Egyetem tehenei az optimális tejtermelés érdekében. 2020. URL: https://kaposvar. szie.hu/kezdolap/hirek/2430-vizagyasmatracokon-pihenhetnek-a-szentistvan-egyetem-tehenei-az-optimalistejtermeles-erdekeben (Letöltés dátuma: 2021.01.04.)
Szúcs, Zs.: Hazai állásfoglalás: a növényi alapú étrendek táplálkozástudományi megítélése. Új Diéta. 2019. 28 (5) 2-6.

Trademagazin: A „hús” hús, a „tej” tej. 2021. URL: https://trademagazin.hu/hu/ahus-hus-a-tej-tej/?utm_source=sendgrid. com \&utm_medi u m = e mail \&utm campaign=website (Letöltés dátuma: 2021.03.30.)

Turtletreelabs.com: Same Milk. Different Method. 2021. URL: https://turtletree. co/process.html (Letöltés dátuma: 2021.03.30.)

Vanga, S. K. - Raghavan, V.: How Well Do Plant Based Alternatives Fare Nutritionally Compared to Cow's Milk? Journal of Food Science and Technology. 2018. 55 (1) 1020. DOI: https://doi.org/10.1007/s13197017-2915-y.

Zingone, F. - Bucci, C. - Iovino, P. Ciacci, C.: Consumption of Milk and Dairy Products: Facts and Figures. Nutrition. 2017. 33 322-325. DOI: https:// doi.org/10.1016/j.nut.2016.07.019

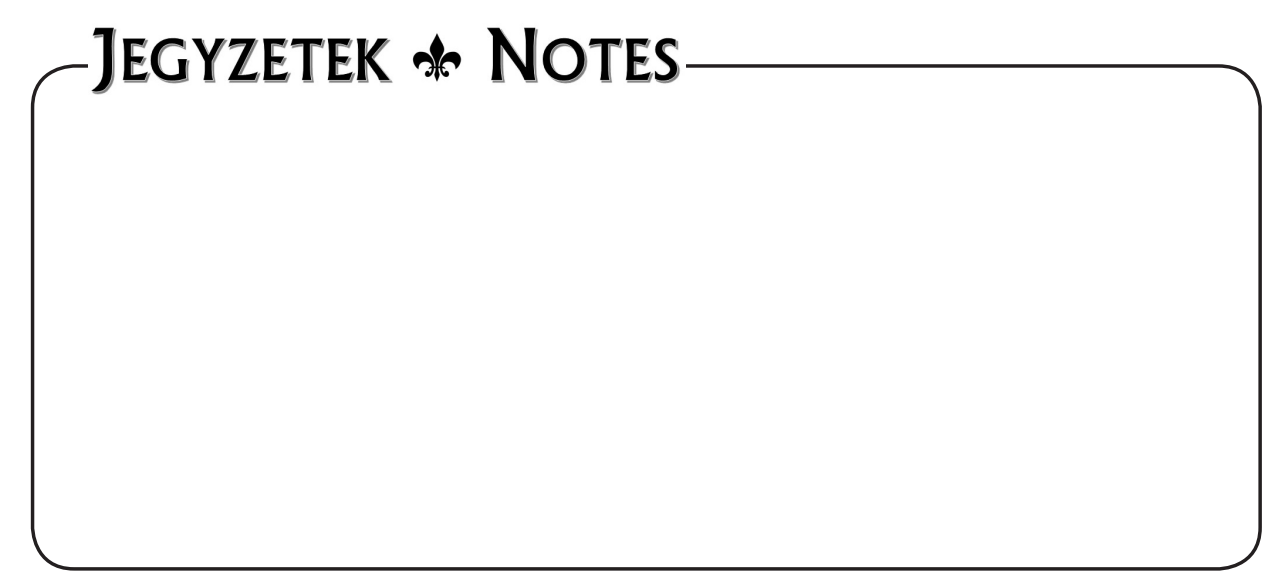

